\title{
I. A. Bláha a počátky sociologie města u nás
}

\author{
I. A. Bláha and the Beginnings of Czech Urban Sociology \\ Dušan Janák
}

\begin{abstract}
The following text deals with the urban sociology of I. A. Bláha - the founder of Brno's
Department of sociology. Bláha's sociology of the city is a pioneering work in the context of Czech sociology and an original contribution to world sociological theory concerning the city. His work presents the first Czech empirical research on the city as well as the first Czech urban sociological theory. His sociological functionalism is an original theoretical approach to the study of the city next to the historical analysis of M. Weber, the psychological view of G. Simmel and the ecological approach of exponents of the Chicago School.
\end{abstract}

KEY WORDS Czech sociology, individualization, rationalization, social function, urban sociology

Někdy si stýskáme, že si svět nevšiml toho, že jsme v naší „malé“, do národního jazyka zavřené sociologii anticipovali strukturální funkcionalismus ve skladebné filosofii J. L. Fischera několik let před Parsonsem, že sociologická idea objektivace byla popsána Chalupným půl století před Bergerem a Luckmannem, že o sebevraždě jako indikátoru krize modernity psal Masaryk před Durkheimem (Masaryka si svět i Durkheim přece jen všimli) (srov. Petrusek 1999). Městu jako fenoménu moderní společnosti věnoval monografii In. A. Bláha (1914) ještě před Chicagskou školou a nezávisle na Parkovi, aniž by se dočkal systematičtější pozornosti. Proto si předkládaná stat' bere za úkol nejen popsat Bláhovu sociologii města, ale také zodpovědět otázku její dobové a pokud možno i soudobé relevance.

\section{Město v Bláhově sociologii}

Fenoménu města věnoval Bláha badatelskou pozornost zejména v počátcích své vědecké kariéry. Sociologie města převažuje v Bláhově sociologické tvorbě (knižní i časopisecké) přibližně do poloviny dvacátých let, tedy zhruba v první třetině jeho badatelského života. ${ }^{1}$ Město, respektive malé město, bylo již tématem Bláhovy disertace z roku 1908. Městu věnoval svou první sociologickou monografii Město. Studie sociologická (Bláha 1914). V tematickém zájmu o město pokračoval roku 1925, kdy vychází jeho třetí monografie spadající tematicky do oboru sociologie města: Sociologie sedláka a dělnika. Později se Bláhův zájem obrací

Sociální studia. Fakulta sociálních studií Masarykovy univerzity, 2/2006. S. 11-32. ISSN 1214-813X.

Za zrození Bláhy-sociologa můžeme považovat jeho disertaci z roku 1908 a za teoretický testament učený tlustospis Sociologie dokončený v oficiálním intelektuálním vyhnanství v 50. letech a vydaný posmrtně roce 1968. 
k jiným sociologickým tématům, k městu se vrací až ve velkém poválečném výzkumu Brna. Prameny k tomuto poslednímu Bláhovu výzkumu však nejsou dostupné a pravděpodobně již ani neexistují. ${ }^{2}$

Bláhova disertace Duše malého města, pokud se vůbec kde dochovala, není ve svém původním znění dostupná. ${ }^{3} \mathrm{O}$ obsahu si ovšem můžeme udělat představu ze seriálu článků uveřejněných v dobových periodikách. Sedlák uvádí, že část práce byla „otištěna v České mysli pod názvem ,Individuum a společnost'. Celá doktorská disertace byla pak publikována jako seriál o jedenácti pokračováních v Lidových novinách v letech 1913 a 1914 s názvem „K psychologii malého města“ “ (Sedlák 1995: 21). Bláhův text v České mysli obsahuje obecný teoretický sociologický rámec, do kterého svou analýzu maloměsta zasazuje, v Lidových novinách nalezneme konkrétnější analýzy maloměstského života psané populární formou.

Ve svém teoretickém přístupu k analýze městského fenoménu se Bláha pokouší o propojení Durkheimova sociologismu s evolucionismem a organicismem (Spencer, Giddings, naši Jozífek a Kunte) a dokonce s tardovským psychologismem. Zcela v duchu durkheimismu konstatuje, že sociální život má své sídlo v celku, nikoli v částech a že pro něj platí jiné zákony než pro individuální bytí: „Život sociální jest synthesa sui generis. [...] Život sociální má zkrátka jiné zákony než život individuální [...] Nic není v životě sociálním, co by nebylo v individuálním vědomí, ale skoro všecko to, co se nalézá ve vědomích individuálních, přichází ze společnosti““ (Bláha 1908: 440). Bláha však nesouhlasí s Durkheimovým principem vysvětlování sociálních fakt jinými sociálními fakty. Přiklání se k tardovským psychologickým principům nápodoby, odporu a přizpůsobení, podle nichž individua interagují v sociálním životě (Bláha 1908: 441-443). Tím získává jeho pozice lehce kontradiktorický nádech. Na jedné straně tvrdí, že sociální život je produktem syntézy s jinými zákony než jaké utváří individuální vědomí, na druhou stranu sahá k principům vysvětlujícím sociální život individuální psychologií. ${ }^{4}$ Propracovanější argument, proč dát přednost Tardeovi, chybí. Chybí i reflexe sporu Tarde - Durkheim, coby sporu o možnost (Tarde) či nemožnost (Durkheim) redukovat sociologii na kapitolu psychologie.

Durkheimovskou argumentaci Bláha využívá pro stanovení statusu společenského vědomí. Umožňuje mu pojednávat o vědomí maloměstských lidí jako o zvláštním sociálním jevu a následně skrze toto sociální vědomí uchopit a vystihnout maloměstský fenomén. Pravděpodobným důvodem pro přijetí tardovského způsobu vysvětlení distribuce představ ve společnosti, byla neschopnost Durkheimovy teorie vysvětlit vznik kolektivních představ, respektive její neschopnost popsat průběh syntézy plodící jevy sociálního řádu. Napovídají tomu Bláhovy rozbory, že zatímco Durkheim pouze konstatuje existenci zákona vývoje v řádu sociálního dění (tj. tvrdí, že sociální dění má vlastní imanentní logiku), Tarde podřizuje

2 Dílčí údaje by pravděpodobně bylo možné zjistit od žijících členů Bláhova poválečného semináře, kteří se na výzkumu podíleli. Pro účely této stati se ovšem nejedná o nezbytný pramen, Bláhova práce $\mathrm{v}$ tomto výzkumu byla pravděpodobně především iniciační a koordinační.

3 Minimálně není zanesena v elektronicky dostupných databázích českých knihoven ani v archivu MU nebo ČSAV.

4 V Tardeho př́istupu se jedná o jakési jednoduché sčítání a odčítání individuálních myslí (srov. Tarde 1901). 
zákony vývoje zákonům prŕčinnosti vyjádřeným v mechanismech napodobení, odporu a přizpůsobení (Bláha 1908: 442-444). Aby bylo učiněno spravedlnosti zadost, dlužno dodat, že se Bláha s tímto rozporem vyrovnal později v sérii statí z roku 1912 (Bláha 1912a-e) věnovaných objektivisticko-subjektivistickému dilematu v sociologii. ${ }^{5}$

Ale zpět k diskutované Bláhově disertaci. Vedle teoretického rámce Durkheimova (který umožňuje uchopit maloměsto jako specifický sociální jev) a Tardeova (který vysvětluje průběh interakcí a rozšíření určitého typu představ na malém městě, respektive ve skupině) doplňuje Bláha svou teoretickou optiku o rozměr evolucionistický či organicistický. Jeho prostřednictvím zařazuje Bláha malé město do celku národní společnosti. ${ }^{6}$ S odvoláním na práce Spencerovy a Giddingsovy konstatuje obdobu mezi vývojem společnosti a vývojem druhů, postupující diferenciaci společnosti spojenou s rostoucí inteligencí. Jedinci i skupiny přitom mohou být na různých fázích vývoje. „(M)ezi divochem a člověkem civilisovaným zdá se býti tak široká propast, jaká je mezi živočichem vyššího

Jeho pozdější argumentaci v otázce vztahu individua a společnosti neubralo na přesvědčivosti ani téměř jedno století uplynuvší od její formulace. Proto stojí zato ji stručně parafrázovat alespoň v poznámce pod čarou. Svoje místo má i při obhajobě určitého objektivistického pohledu na město jako na emergentní jev nového řádu, které odlišuje Bláhovu pozici např́ílad od pojetí Weberova (viz 3. část textu). Bláhovu argumentaci lze rozdělit na dvě části takto: (I) Proti subjektivismu, tj. ,atomistické redukci společenských jevů na individuální hnutí“, mluví zjištění, že: (1) Úplnou přččinu ani podmínky, proč určitá idea není pouze silou individuální, ale stává se kolektivní, nelze nalézt vždy jen v individuální mentalitě. (2) Je řada idejí, které mají význam pro individuum, ale nikoli pro společnost (jsme schopni odlišit, alespoň analyticky, individuální a kolektivní představy). (3) Psychologismus či subjektivismus se dopouští toho, že redukují sociální jevy na príliš prríčiny jednoduché. Tím zbavují sociální jevy jejich sociálnosti a sociologii připravují o důvod vědecké existence. Zde Bláha používá Durkheimův argument, že takovéto redukcionistické snahy jsou podobné snahám redukovat biologii na kapitolu fyziky, popisujíć životní procesy jazykem síly, gravitace, rychlosti, hmotnosti atp. (4) Jevy, které vznikají interakcí, jsou obvykle nového rádu, který se nedá předem předvídat. Proto je nutné je brát jako jevy sui generis, i když zpětně lze jejich genezi vystopovat do kvalitativně jiných rovin jsoucna. (II) Proti sociologickému objektivismu lze namítat, že: (5) Neexistuje žádný empirický doklad toho, že by vědomí individua nemohlo vzniknout bez psychosociologické interakce, aspoň ve své nejprimitivnější formě. (6) Není dokázáno, že by tato interakce existovala před vznikem individuálního vědomí. Pro uvedenou argumentaci srov. zejména Bláha 1912b. V krajních verzích obou teorií se tedy podle Bláhy nachází něco, co odporuje empirii nebo není dostatečně prokazatelné. Subjektivismus zbavuje sociální fakta specifického rázu, objektivismus zase popírá duševní iniciativitu. Chybou je jednostrannost, $\mathrm{k}$ níž dochází vytyčením logické priority jednoho oboru sociálního života nad druhým. Definitivní pozitivní překonání tohoto rozporu (sociologického subjektivisu a objektivismu) a syntézu obou stanovisek Bláha dovršuje zejména v pracích z let dvacátých v konceptu tzv. „sociální situace“. Vzhledem k tematickému i prostorovému omezení rozsahu předkládané stati odkazujeme ke konceptu sociální situace na př́ślušnou literaturu: její první formulace nalézáme v Sociologii dětství (Bláha 1927); stručně a souhrnně je tato koncepce popsána v Sociologii (Bláha 1968: 11-16).

6 Metafora organismu byla na přelomu století poměrně široce používanou analogií pro postižení společenského života. Například i Durkheim, který jinak Spencera nijak nešetří před svou kritikou (zejména v otázce vztahu diferenciace společnosti a dělby práce) a celkově začíná velké tažení proti redukci sociologie na kapitoly jiných věd, metaforu organismu přejímá a používá bez komentáře. 
organismu a ústřicí přisedlou ke skále,“ píše Bláha (Bláha 1908: 439-440). Analogicky ke Spencerovu dělení společností na vojenské a průmyslové, které zároveň představují dva vývojové typy, dělí Bláha národní společnost na dvě skupiny - venkovskou a městskou. Venkov představuje stadium vojenské, město stadium průmyslové. Společnost je v přechodu směrem k městskému typu. Malé město je místem střetu těchto dvou společenských vývojových fází (Bláha 1908: 444-445). „Všechen pokrok hospodářský, politický, duchovní i mravní zrodil se na městské půdě. [...] Malé město [...] zůstává na rozhraní. Ve všech oborech jeho života zápasí o ně autorita a svoboda, tradice a pokrok, rozum a mythus, sobectví a solidarita“ (Bláha 1913-1914, 8. část: 2). Bláha shledává tuto rozpolcenost např́klad v rovině náboženské nebo politické. Popisuje rozpor mezi konzervativní společenskou strukturou spojenou s náboženským kolektivismem a postupujícím náboženským individualismem projevujícím se emancipací od církví: „Malé město představuje typ přechodní, [...] váhající mezi náboženským kolektivismem a individualismem, mezi poslušností a svobodou“ (Bláha 1913-1914, 7. část: LN 30. 1. 1914). Podobně argumentuje i v otázce politického volebního chování: „,(Z) boje obou tendencí, odstředivé, solidaristické a dostředivé, maloměstsky egoistické, vzniká často podivná křivolakost. [...] Do obce volí konzervativně, do země třebas a do říšské rady pokrokově..." (Bláha 1913-1914, 11. část: LN 14. 3. 1914). Prvek tradice, bránící plnému uskutečnění společenského konsensu na pokrokových demokratických základech, odhaluje Bláha v maloměstské stavovské tuhosti. Tato tuhost je demonstrována $\mathrm{v}$ neprátelském vztahu všech maloměstských vrstev k rolnictvu i ostrým vymezení mezi sebou navzájem.

Bláhův výzkum malého města je zajímavý také po stránce metodologické. Jedná se o jeden z prvních (ne-li vůbec první) českých sociologických výzkumů prováděných pomocí dotazníku. Ke svým závěrům o malém městě Bláha dospívá na základě analýzy asi 150 dotazníků rozeslaných „,do malých měst českých, moravských a slovenských na jednotlivce nejrůznějších stavư“" (Bláha 1913-914, 1. část: LN 23. 7. 1913). Podrobnější metodologické údaje o konstrukci dotazníků, výběru respondentů a způsobu zpracování nejsou bohužel dostupné. Z publikovaného textu však vyplývá - řečeno dnešní terminologií - že Bláhova metoda je kvalitativní analýzou odpovědí na převážně otevřené otázky. J. Sedlák souhrnně parafrázuje pravděpodobný obsah dotazníku, jak jej lze rekonstruovat z publikovaného textu: „Co se vám líbí na vašem malém městě a s čím jste nespokojeni? Jaký je společenský život ve vašem malém městě? Pracujete rád? Nač myslíte při práci? Č́m se zaměstnáváte večer? Otázky k sociálnímu cítění maloměstského obyvatelstva. Otázky o poměru maloměstských vrstev výrobních $\mathrm{k}$ maloměstské inteligenci. Veříte $\mathrm{v}$ Boha? Chodíte do kostela? Mají maloměstské vrstvy nějaké upř́ímné potřeby náboženské? Jakou úlohu hraje na malém městě kněžstvo? Co soudíte o rozdělení národa na politické strany? Co očekáváte od své politické strany? Čím je jednotlivým vrstvám maloměstským politika?“ (Sedlák 1995: 111). Je pravděpodobné, že některé otázky byly v dotaznících formulovány jinak a je možné, že ani tematicky není předložený soubor úplný. Z textu je také patrné, že Bláha pracuje s dotazníky opatrně a kriticky. Je si vědom omezené možnosti generalizace. Proto často ani neuvádí absolutní nebo relativní četnosti. S dotazníky pracuje, jak je běžné např́ílad u analýz kvalitativních rozhovorů, tj. uvádí typické ilustrativní ukázky odpovědí nebo definuje a klasifikuje typy odpovědí vztahující se $\mathrm{k}$ určitému tématu. 
Ze zmiňovaného výzkumu vychází také Bláhova stat’ z roku 1912 „Smysl pro umění na malém městě“. V ní Bláha zjištuje absenci svérázného maloměstského estetického slohu. Její príčiny spatřuje $\mathrm{v}$ dřívější době $\mathrm{v}$ útisku, $\mathrm{v}$ době vzniku textu (tj. roku 1912) v přechodu na nové podmínky - s průmyslovou revolucí dochází $\mathrm{k}$ zániku některých řemeslných a uměleckých tradic, k přetváření povolání. Vidí však také určité kličící zárodky nové estetické tradice malého města. Některá malá města zakládají novou estetickou tradici na svých uměleckých památkách, jiná na krásách okolí, další zase na určité dobové atmosfeře, která městem prostupuje.

Vedle přetisku či upraveného vydání výňatků z disertace se Bláha mezi lety 1911 a 1920 věnoval fenoménu maloměsta také $v$ několika dalších článcích, $v$ nichž se zaměřil na některé dílčí aspekty maloměstského života. Zdrojem poznání mu byl také jeho vlastní život profesora na reálce v Novém Městě na Moravě (1904-1919). V článku „Malé město a jednotlivec“ (Bláha 1920) se zamýšlí nad fenoménem veřejného mínění a jeho tlakem na individuum. „Kdykoli vstupujete do společnosti, jakobyste musili projíti pod jakousi mírou předpisů, požadavků $[\ldots]$ společnost na nás působí jistým tlakem, jistou mocí svých předpisů, přikázání, názorů, jichž souhrnu ř́káme veřejné mínění, veřejná morálka. Ona proměňuje naše já domácí, v němž se každý projevujeme jinak, v jisté já společenské, v němž vypadáme všichni podobně“ (Bláha 1920: 1). Pojem veřejného mínění Bláha pojímá úžeji než jak je tomu dnes, kryje se mu především s představami o žádoucích normách chování a života. Obsah těchto veřejných hodnotových soudů vyplývá z celkového způsobu života všech členů skupiny, respektive malého města. Proto „není [veřejné mínění - D. J.] stejné v Brně, Praze, Jihlavě, Žd'áře, Novém Městě“ (Bláha 1920: 1). Veřejné mínění či veřejná morálka potom tvrdě dopadne na ty, kteří se jí vymykají, at' v pozitivním nebo negativním smyslu.

Pozitivnímu vymezení maloměstské morálky se Bláha podrobněji věnoval ve stati uveřejněné v České mysli už roku 1912. Konstatuje existenci řady dílčích skupinových morálek všedního dne, které se na malém městě vzájemně kříží. Avšak vedle nich „malé město má svou morálku též jako jednotný celek“ (Bláha 1912g: 96). Duševní život na malém městě se točí kolem konzervativních tradic, chápaných zejména hospodářsky, utilitaristicky, které vymezují i obsahy morálky (šetrnost, dědění, ženění a vdávání, úcta $\mathrm{k}$ autoritě, poslušnost k církvi) (Bláha 1912g: 101). Vedle toho přistupuje i neprátelský postoj vůči př́chozímu cizinci. Maloměstská morálka je zaměřena směrem dovnitř, je to morálka skupinového egoismu (Bláha 1912g: 98). Ovšem „netřeba ji proto odsuzovat. Nebot’ je to morálka sebezáchovy tradice“ (Bláha 1912g: 101). Nebyl by to ale Bláha, aby čtenáře nepoučil o žádoucím vývoji. „Nejedná se [...] o vyvrácení maloměstských tradic [...] pouze o jejich pozměnění“ (Bláha 1912g: 102). Vedle úlohy silných osobností, schopných pozměnit maloměstskou morálku v souladu s pokrokovými ideály, tzv. ideály humanitními, vidí Bláha zcela realisticky roli státu. „Důležitým uskutečňovatelem a podporovatelem pokrokového pozměňování maloměstských tradic je dnešní zemská státní centralisace, [která - D. J] urychluje pokrok materiální i mravni“" (Bláha 1912g: 102).

Není třeba se dále a podrobněji věnovat Bláhově sociologii maloměsta. $Z$ představení této části Bláhovy rané sociologie je patrné, že ho zajímají především psychické formy maloměstského života, životní návyky a hodnoty. Sociografické údaje o velikosti malých měst či jejich morfologii nebo analýza komunikačních drah v podstatě chybí. Maloměsto je zasazeno 
do určité teorie historické sociální dynamiky, jejíž principy se zrcadlí v maloměstských psychických a sociálních formách (volební chování, náboženský život, morálka, stavovská organizace atp.). Malé město je pojednáno jako jev, v němž se stýká tradice s pokrokem, sociální statika s dynamikou, konzervativní s moderním. Prvkem statickým, tradičním, konzervativním je v celku národní společnosti venkov. Na opačném konci vývojové metafory stojí město s atributy pokrokovosti, dynamiky, modernosti. Malé město je ohniskem přechodu. Tento na první pohled jednoduchý syžet Bláha neopouští ani později, jak bude patrné na jeho sociologii města a venkova. Umožňuje mu postihnout probíhající společenskou dynamiku i charakterizovat jednotnou optikou stávající společenské městské formy. Jako problematický prvek se v Bláhově pojetí dynamiky jeví, alespoň z pohledu dnešní sociologie, přiřazování hodnotícího znaménka směru toho vývoje. Achillovou patou je modernistický pojem pokroku. Není možné se zde věnovat analýze tohoto pojmu v Bláhově sociologii. Nelze jej však přejít zcela bez poznámky, protože je stavebním kamenem jeho nazírání na sociální dynamiku. Omezíme se však na konstatování, že přestože Bláha ve své sociologii toto modernistické nazírání v podstatě nikdy neopustil, neustále se k problematice směru společenského vývoje a směřování vrací i na metateoretické rovině. Pojetí pokroku je u něj podrobováno revizi a později od něj v zásadě upouští. Místo pojmu ,pokrok“ stále více pracuje s pojmem „funkce“, kterou chápe v původním durkheimovském významu jako de facto teleologicky definovanou činnost směřující k uspokojení určité potřeby. Takovéto pouze zdánlivě nehodnotící pojetí funkce doplňuje teorií vzniku společenských hodnot, které podobně jako potřeby určují lidské jednání a jsou vůdčími prvky společenské dynamiky. Z ideje pokroku se postupně vytrácí důraz na neustálé a nezvratné společenské zlepšování. Idea pokroku je pro Bláhu nakonec především myšlenkou sloužící k odmítnutí cyklického nebo periodického (tj. naivně dialektického) pojetí dějin ve prospěch pojetí kontinuálního. Tak je tomu např́iklad již v roce 1909, v textu věnovaném problematice národa. Národní sebevědomí je pro Bláhu jevem historickým, výsledkem společenského pokroku. Pojem pokroku přitom kromě zmíněného zakotvení pojetí historie slouží k odmítnutí nadpřirozených faktorů v průběhu vývoje, stejně jako náhody. Pro kontext tematického zaměření této stati je zajímavé propojení idejí pokroku, národnosti a města. Ohnisky a východisky národnosti jsou pro Bláhu právě města, která jsou zároveň nositeli pokroku a dynamiky. Pokud bychom vymazali z pojmu pokroku jeho hodnotící konotace a ponechali rozměr dynamiky a vývoje, vyzní nám Bláhova analýza velmi přesně. Klíčovým faktorem pro konstituci národnosti byla podle Bláhy politická moc, která vytvořila stmelené regiony. Vědomí stejné rasy a podobná kultura latinská a křest’anská tomuto vývoji jen napomohly. ${ }^{7}$ Vědomí jednoty se šířilo z městských středisek na venkov (díky komunikačním technologiím,

Město se jeví např́iklad i ve Weberově perspektivě jako region politické stejnorodosti, fenomén vyvazující se z tradiční formy panství; viz Weber: Economy and Society 1212-1368. Bez zajímavosti není ani teritoriální Bláhův předpoklad vzniku národnosti a reálného národního zakotvení. O jeho netriviálnosti nás přesvědčí analýzy E. Rádla (2003). Rádl dokládá absenci principu teritoriality $\mathrm{v}$ německé národní ideologii. Německý národ je z pohledu této ideologie čistě společenstvím krve. Proto nemá svou zemi, respektive jeho zemí je každá, kde žijí obyvatelé německé národnosti. Rádlova předválečná prognostika dalšího možného vývoje německého národa se smutně shoduje s historickou skutečností. 
vzdělání, buditelům). Stoupalo vědomí jazykové i celkové př́ibuznosti, které postupovalo od intelektuálů $\mathrm{k}$ širokým vrstvám a překročilo nakonec i hranice politické moci. Bláha konstatuje národnostně emancipační změny poprvé ve Francii a uzavírá svou stat' prognosticky prozíravě: „A podle tohoto zákona pokroku prochází všecky národy, i Rakousko padne“ (Bláha 1909: 375). Tento téměř cimrmanovský obrat („,byli jsme před Rakouskem, budeme i po něm“) však nevyznívá v kontextu Bláhovy práce jako nutný zákon zlepšování lidského pokolení. O kladném charakteru vývoje, o jeho dobru a prospěšnosti, nás kromě slova „pokrok“ $\mathrm{v}$ textu nic jiného nepřesvědčuje. Jeho funkce je spíš v tom podtrhnout určitou objektivní charakteristiku společenských procesů vedoucích $\mathrm{k}$ národnímu uvědomění a formování národních států. Pojem zákona pak umožňuje Bláhovi vystihnout objektivitu dění. Pojem pokroku zase odmítá cyklický a dialektický charakter tohoto dění.

$\mathrm{K}$ tematickému posunu $\mathrm{v}$ Bláhově sociologii města se dostáváme $\mathrm{v}$ př́padě jeho habilitace. Má podobu přenesení zájmu od maloměsta $\mathrm{k}$ městu. $\mathrm{S}$ trochou nadsázky to vypadá, jakoby maloměsto, zpracované v disertaci (1908), bylo Bláhovi tréninkem na velké město, zkoumané v práci habilitační (1914). Habilitační spis Město. Studie sociologická vyšel tiskem roku 1914. V celku Bláhovy sociologie představuje tato kniha také vymezení obecného metodologického př́stupu k sociálním jevům, který si Bláha podržuje i u dalších sociologických monografií:

Při každém útvaru a jevu sociálním [...] nutno si všimnouti jeho vývojových fasí předchozích, jež určují fasi př́tomnou, nutno se zastaviti u specifických př́ícin jeho vzniku a stopovati, jaký vliv ty prŕčiny měli na jeho strukturu materiální a sociální, jakož i na jeho funkce.Vše to tvoří organický celek a zvláštní povaha sociálního jevu plyne teprve z toho všeho dohromady. Tak také při městském životě, rozdělujeme-li dějiny vzniku a vývoje města od příčin vzniku jeho a jeho funkcí, a toto vše zase od sociální látky tvořící městský organismus, jeho organisace hmotné i sociální, jakož i jeho funkcí, činíme tak jen k vůli usnadnění analytické práce... (Bláha 1914: 19)

Prríčiny vzniku, struktura a funkce. To jsou tři metodické otázky, které je třeba podle Bláhy zodpovědět při zkoumání sociálních jevů. Podle tohoto schématu je sepsáno nejen Město, ale i další sociologické monografie (Sociologie sedláka a dělnika, Dnešní krise rodinného života, Sociologie inteligence ad.). Město je vlajkovou lodí Bláhova sociologického př́stupu ještě z jednoho důvodu. Představuje př́stup monografický, zaměřující se na jednotlivá sociologická témata. Takový př́istup, který je dnes v podstatě samožrejmostí, nebyl v době budování disciplíny zcela automatický. Protipř́íkladem budiž v českých podmínkách systém Emanuela Chalupného zachycený v sedmi svazcích jeho Sociologie. Základy své metody si Bláha dovezl pravděpodobně z Francie.Ve školním roce 1908/1909 Bláha absolvoval roční studijní dovolenou v Paříži. Kromě práce v knihovně, kde sbíral materiál pro svou habilitaci k sociologii města, sociologii národa, války a k dějinám sociologie (Bláha 1997: 31), navštěvoval přednášky na Sorbonně. Vliv Durkheima a Wormse (se kterým se i spřátelil) měl dopad na jeho definitivní príklon $\mathrm{k}$ sociologii a zanechal své stopy také $\mathrm{v}$ deklarované metodické trojčlence zmiňované výše. $\mathrm{V}$ podstatě stejné metodické požadavky vysvětlení společenského jevu na základě odděleného vysvětlení jeho př́čin a funkcí nalezneme v Durkheimových Pravidlech sociologické metody, v kapitole nesoucí př́iznačný název „Pravidla pro výklad společenských jevü“ (srov. Durkheim 1926: 122-156). Tento durkheimovský metodický př́stup lze odlišit od dalších velkých sociologických tradic - např́klad od weberovské a simmelovské, o kterých bude pojednáno v prríslušných částech textu. 
Vliv francouzské tradice je př́tomen i v Bláhově výkladu příčin vzniku měst. Výkladovým principem je mu dělba práce. Město je podle něj „,produktem specialisace práce mezi venkovem a vrstvou přebytečných [řremeslníků a obchodníků - D. J.] při intensivnějším naturálním hospodářství, dávají vznik nové tř́dě společenské, střednímu stavu, jehož kolektivní pouto tvoří společné zájmy hospodářské, právní a politické uvnitř společných hradeb. A zase uprostřed této vrstvy další specialisací vznikají nová povolání, nové stavy, nová střediska zájmů“ (Bláha 1914a: 52). Ovšem Bláhův výklad je důsledně sociologický v intencích Durkheimových; specifikum městskosti neleží v př́činách jejího vzniku. Jakmile městská společnost vznikla, liší se od venkovské skupiny podstatně a $\mathrm{v}$ řadě ohledů, je sociálním jevem sui generis. Dominující charakteristiky nového sociálního typu jsou Bláhovými slovy tyto: „Městskost sociálních jevů vyjádřena jest pokrokem a tendencí $\mathrm{k}$ individualisaci, $\mathrm{k}$ racionalisaci a k solidarisaci“ (Bláha 1914a: 17). Pomocí těchto pojmů analyzuje město v otázce jeho prostorového uspořádání, sociální struktury a sociální funkce, politického fungování městské samosprávy a konečně i vlivu města na lidskou psychiku.

Nová hmotná forma města je podle Bláhy odrazem nového kolektivního života. Např́klad hradby mají nejen obranou funkci, ale zároveň symbolizují městskou celistvost, blízkost domů odráží sociální a etickou blízkost jednotlivců (solidaritu) a široké městské ulice jsou určeny pro uspěchané měš'any. $V$ městské architektuře se zrcadlí odpoutanost od půdy: rozum se ve městě obklopil sebou samým skrze své výtvory - umělé prostředí, architekturu diktovanou nikoli př́rodní nutností, ale estetickým slohem. Hlavní sociální novum města tvoří vzniklý střední stav tvořený kupci a řemeslníky. Oproti střednímu stavu venkovskému je charakterizován odpoutaností od půdy, vlastnictvím výrobních prostředků a přesunem k duševní práci. Rozdíl mezi měštany a venkovany je v první řadě v povaze práce. Obchod odpoutaný od půdy a zemědělské výroby nabývá stále více povahy kalkulu, racionalizuje se. Dř́vější kupec byl kramářem s vozem plným zboží, moderní městský kupec pracuje duševně, těžištěm jeho práce je kalkulace a spekulace. Kultivace peněžního hospodářství a kapitálového podnikání ve městech vede ke vzniku složitých sociálních vazeb a styků, které Bláha interpretuje v intencích Durkheimových. Nejdůležitějš́ charakteristiky vzniklé městské sociální skupiny vystihují následující Bláhova slova:

Co však hospodářský život městské skupiny nejvíce karakterisuje, [...] jest ta okolnost, že [...] nesl v sobě všecky zárodky pozměňování, vývoje, pokročivosti. (Bláha 1914a: 136) Sociální funkce města spočívá tedy v tom, že se stalo místem dělení práce a množení potřeb, že dalo vznik novým povoláním a organisovalo novou společenskou vrstvu, že vůbec pro svou sociální osobitost [...] stalo se hnací silou všeho sociálního vývoje. (Bláha 1914a:102-103) Bylo jejím úkolem (buržoazie - D. J.) organisovati práci, kapitál a vědění a učiniti z posledních dvou hybné síly novodobé společnosti. Tím se stala tvořitelkou všech kulturních hodnot moderní doby, stala se solidarisačním, individualisačním a racionalisačním elementem společnosti. V tom jest její zvláštní společenská funkce. (Bláha 1914a: 206; kurzíva autor)

Bláha zasazuje sociální městský fenomén do teorie společenského vývoje, naznačené již v disertaci. Hybnou silou moderní společnosti je podle něj kapitál a vědění, obojí je městskou doménou, tím, co charakterizuje městskou práci. Bláhovo pojetí solidarity plynoucí z povahy městské práce lze vystihnout Durkheimovým konceptem organické solidarity. Tato solidarita má zároveň racionální základ, protože plyne z uvědomění si sociální blízkosti, z racionální 
abstrakce, k níž se došlo společenskou diferenciací (odkázání na mnohé) a interakcí (množství kř́žíících se tlaků ve městě, větší množství sociálních světů, které individuum ve městě obývá). Městská sociální individualizace (politickým základem města je svobodné individuum, volená městská samospráva je kolektivní representací tohoto nového individualismu) je doplňkem nové solidarity a výsledkem rostoucí společenské diferenciace. Bláha moderní městskou individualizaci interpretuje optimisticky jako výsledek změny egoistické pokrevní solidarity v solidaritu celospolečenskou, jak bylo naznačeno již v jeho pojetí vzniku národního sebevědomí (viz výše). Moderní svět podle Bláhy je a ještě více bude určován městským životním stylem. Nejen kapitálem, ale i novým typem vědění, které je produktem městského života. Objektivaci nové městské psýché nalézá Bláha v umění, právu, vědě apod. Vědecká racionalita potřebuje nejen psychické, ale i sociální podmínky, které jsou ve městě prítomny ve větší míře než na venkově. Teprve vysoký počet obyvatel měst a hustota jejich interakcí vytvářejí podmínky společenské syntézy, projevující se na psychické úrovni „vědeckou metodou práce a myšlení“. „Ta jest výsledkem sespolečenštěných inteligencí městské skupiny a nemohla nikdy vzniknouti na venkově...“ (Bláha 1914b: 15). „Bez kolektivní rozumové abstrakce, dané právě ustavičným přizpůsobováním individuí celku a nutností mít mnohé s mnohými společné [...] nebylo by objektivní pravdy. Čím více jest společnost diferencována, tím více možno předpokládati, že se celek společnosti blíží objektivní pravdě“ (Bláha 1914b: 8). Nebudeme na tomto místě zabíhat do složité a vleklé diskuze na téma vědecké objektivity a analyzovat adekvátnost či neadekvátnost Bláhova pojetí. Uvedené Bláhovy teze nám zde spíše ilustrují komplexnost jeho analýzy a úroveň obecnosti, na níž se pohybuje. Město. Studie sociologická představuje sociologickou teorii města v plném smyslu tohoto termínu. Nejen že je oproti disertaci, která měla ráz empirického výzkumu, prací teoretickou, ale zároveň zasazuje fenomén města do určité sociologické teorie společnosti a modernizace. Bláhovi se daří spojit v jednotné koncepci analýzu dějin a př́čin vzniku městského fenoménu s analýzou městské struktury a rolí fenoménu města v moderní společnosti. I přes velké množství historických a ekonomických děl, o které se ve své knize opírá, je jeho analýza v rovině interpretace bytostně sociologická.

Třetí a poslední Bláhova velká práce z oboru sociologie města - Sociologie sedláka a dělníka (1925) - je, stejně jako jeho první práce ze sociologie města, opět prací empirickou. Po položení základů sociologické teorie města se Bláha vrátil opět k jeho empirickému výzkumu. Podtitul tohoto spisu zní $K$ sociologii společenských vrstev. Tím je vystižen i cíl práce, rozvedený $\mathrm{v}$ úvodu, neboli vystihnout dělnictvo a rolnictvo jako specifický sociální typ; ukázat, jak povolání a práce utvárí jistý typ, tj. soubor tělesných, duševních, morfologických a mravních vlastností a rysů charakteristických pro určitou skupinu (Bláha 1925a: 8). Deskripce dělnických a rolnických vrstev není z hlediska přiblížení Bláhovy sociologie města relevantní. $Z$ tohoto hlediska je třeba zmínit dva momenty. První je obecnější a týká se metody Bláhovy práce. Autor zde nevychází z dotazníkového šetření, jako v př́ípadě svého prvního výzkumu, ale opírá se o vlastní (kvalitativní) pozorování konaná v dělnickém i venkovském prostředí, o analýzu a interpretaci existujících statistik (spotřebních, zdravotnických, bytových apod.), pracuje s rozsáhlou literaturou věnovanou tématu. Netradiční je jeho využívání umění a literatury nejen jako metafory, ale prímo jako studijního materiálu. „Vyjádřit typ dovede zatím spiše umění než věda. V tom ohledu umění vědu značně předběhlo, “ píše Bláha 
(1925a: 8). Umění je podle něj sice formou neobjektivního poznání, ale netřeba jej proto zavrhovat. Pokud si badatel zachová kritický odstup a nabude určité zkušenosti, může umění úspěšně používat jako nástroj interpretace sociální skutečnosti. V tomto rysu metodického využívání umění a literatury v sociologickém výzkumu Bláha naplňuje jednak masarykovskou tradici, jednak intence dobového noetického syntetismu. ${ }^{8}$ Bláhovy analýzy svou komplexností a kombinací různých výzkumných technik připomínají subtilní výzkumy životního stylu P. Bourdieuho. Kupř́ikladu nejen to, co si dělník obléká, ale i způsob, jakým různé šaty nosí, pokládá Bláha za relevantní výpověd’ o jeho životním stylu (srov. Bláha 1925a: 43-44). Je pravděpodobné, že takovýto komplexní přístup kombinující kvalitativní a kvantitativní techniky, například interpretaci statistik a zúčastněné pozorování, byl aplikován i ve zmiňovaném poválečném výzkumu.

Druhý moment se týká Bláhovy analýzy stávajícího i žádoucího poměru města a venkova. Tuto problematiku vztahuje ke své teorii modernizace. Město je nositelem pokroku a změny, venkov nositelem tradice a stability. Funkcionálním určením jsou oba nezbytné pro harmonické fungování společnosti. Jde o to, aby „vzájemnou pomocí oba činitelé byli posilováni ve vykonávání své specifické funkce v národní společnosti“ (1925a: 182). Právě specifické pojetí funkce v Bláhově sociologii umožňuje plynulou přesmyčku od nehodnotící analýzy k definici žádoucího směru společenského vývoje. I když společenská změna a kulturní hodnoty vznikají v moderní společnosti především na městské půdě, nevidí Bláha v urbanismu jednostranně žádoucí směr vývoje. Tradiční otázka klasické sociologie po poměru společenské statiky a dynamiky je u Bláhy aplikována na poměr venkova jako nositele stability a města jako dynamického prvku. Pro žádoucí vztah města a venkova razí Bláha novotvar „rurbanism, vyrovnání mezi městem a venkovem, duchem a hmotou, kulturou a př́rodou ve smyslu zduchovnění hmoty a zkulturnění př́irody“ (1925a: 181). Toto ,zduchovnění hmoty“ a „zkulturnění prŕírody“ vidí ve zracionalizování venkovské zemědělské práce skrze ,vědu a stroj“, směřující ke zlepšení životních podmínek. Dále v osvětě a novém adekvátním vzdělání, vedoucím k uvědomění si společenské funkce venkova, a tím ke zvýšení společenské solidarity.

Společenská realita padesátých let, kdy byl oficiálně odsunut do intelektuální izolace, umožnila Bláhovi zhodnotit adekvátnost jeho prognózy urbanizace venkova (plynoucí z jeho teorie modernizace) i naplnění jeho požadavků vedoucích k racionalizaci a solidarizaci venkova. K urbanizaci sice došlo, k žádoucímu ,rurbanismu“ již méně. „Venkovský člověk byl vržen náhle, někdy násilím [...] do prostředí nového, industrializovaného, z jednoho technického věku do technického věku jiného," poznamenal si Bláha do osobních zápisků v roce 1958 (Bláha 2004: 215). Nejenže byl ,venkovský člověk odtržen od půdy a svých hospodářských zvyků a tradic, ale byl uvolněn i od jiných tradičních vazeb života“ (Bláha 2004: 216). Urbanizace a industrializace venkova vedla sice k větší racionalizaci, nikoli však solidarizaci. Např́klad rodina, tradiční opora a hodnota venkova, byla novým hospodářským řádem rozrušena. Práce

Na rozborech ruské literatury je postaven Masarykův spis Rusko a Evropa, své čtení Dostojevského Masaryk využívá v Sebevraždě. K Masarykovu využívání literatury v sociologii viz Nový 1994 („Literatura v Masarykově myšleni“) či Petrusek 1994. O syntetismu jako noetickému názoru u nás na přelomu století pojednal Zouhar (2000). 
se „odstěhovala z domova“ a venkovský člověk se v mezdním režimu stal ,atomizovanou jednotkou, jež sice ještě pracuje na půdě, ale je osobně a citově odpoutána od půdy“ (Bláha 2004: 215). V retrospektivním srovnání s Bláhovou publikací z roku 1925 odpovídá rolník padesátých let městskému proletariátu let dvacátých - je odpoután od půdy, nevlastní výrobní prostředky (obojí tvoří podle Bláhy reálný základ životních hodnot), je prací odveden z domova, kde společná práce na společném podniku vytvářela silná pouta skupinové solidarity. Došlo v podstatě k proletarizaci rolnických vrstev a jejich sociálnímu odcizení. Díky revolučnímu přechodu ke kolektivismu se fyzicky rozrušily tradiční vazby, ale nebyly nahrazeny novými vazbami duchovními, kolektivními, celospolečenskými. Poválečný vývoj Bláhovy zapadal do jeho sociologického vidění města, jak je formuloval dávno před válkou. Není problematické domyslet možnou a pravděpodobnou Bláhovu interpretaci anomických tendencí odehrávajících se na venkově. Ztráta tradiční solidarity a absence solidarity nového typu je způsobena tím, že některé složky společnosti neplní náležitě svoji funkci. Z prèedchozích úvah vyplývá, že to jsou pravděpodobně složky vůdcovské, osvětové a výchovné. Odpověd’ na otázku, které sociální subjekty tyto funkce nesou a proč svou funkci neplní, je otázkou přesahující téma tohoto textu i Bláhovy sociologie města. Proto v tomto bodě své úvahy a interpretace Bláhovy skutečné i možné sociologie zastavíme a pozornost přesuneme $\mathrm{k}$ otázce role a místa jeho bádání v rámci české sociologie.

\section{Bláhova sociologie města $\mathbf{v}$ české sociologii}

I když první českou prací spadající do oblasti zájmu sociologie města je pravděpodobně Chalupného spisek Poméry dělnictva táborského (Chalupný 1903) - inspirovaný Engelsovou prací Postaveni dělnické třídy v Anglii -, nelze v Chalupného př́ípadě ještě mluvit o „čisté" sociologii města. Město jako sociální jev zasluhující si zvláštní sociologickou analýzu se dočkalo svého zpracování až v díle Bláhově. Jeho kniha Město. Studie sociologická představuje první skutečně českou a skutečně sociologickou teorii města. $\mathrm{V}$ předchozím textu byl ukázán vývoj Bláhovy sociologie města od empirického zpracování fenoménu maloměsta na základě jednoduché dotazníkové metodologie k vybudování sociologické teorie města a dalšímu návratu k empirické práci, po metodologické stránce daleko komplexnější.

Posunutí zájmu od města $\mathrm{k}$ fenoménu vesnice bylo způsobeno mj. společenskou a politickou objednávkou a institucionálními podmínkami české sociologie. Roku 1924 byla založena Československá akademie zemědělská. Jejím prezidentem se stal ministr zemědělství (1922-1926, 1932-1935) a pozdější ministerský předseda (1935-1938) Milan Hodža. Hodža byl také členem Masarykovy sociologické společnosti. $Z$ jeho popudu byla při zemědělské akademii zř́zena komise pro sociologii venkova. Jejím předsedou byl jmenován Bláha a náměstkem E. Chalupný (srov. Voráček 1999). V české sociologii se tak začalo pracovat spíše v oblasti sociologie venkova. V roce 1931 sice Bláha přednesl v Masarykově sociologické společnosti přednášku s názvem Dělnický výzkumný ústav, v níž předložil a argumentačně podpořil návrh takto zaměřeného výzkumného pracoviště, jež by se orientovalo též na obyvatele měst, ale zůstalo jen u návrhu.

Soustavněji a monograficky se městem po Bláhovi zabývali dále až pražští sociologové na konci 30. let v kolektivním díle sociografického charakteru Sociologické studie o poměštováni pražského okoli (1938). Na této publikaci se významně autorsky podíleli O. Machotka, 
A. Boháč a zejména Z. Ullrich. Posledně jmenovaný aplikoval na výzkum suburbanizace Prahy principy sociální ekologie, zřejmě přejaté z americké sociologie. Machotka, Ullrich a Galla také publikovali v roce 1939 statě o poměru města $\mathrm{k}$ venkovu. ${ }^{9}$

Město, jako typicky moderní sociální fenomén, se přirozeně objevovalo i v pracích řady dalších autorů: například těch zabývajících se dělnickou otázkou; sociální patologií - např́klad Foustka nebo Masaryk, který analyzuje sebevraždu mj. jako městský jev (2002: 144); je jisté, že fenoménu města se věnoval i Emanuel Chalupný, který psal „z hlediska sociologického" asi úplně o všem. Nejedná se však o cílený zájem a bádání v sociologii města, město je zde spíš v roli komparsu a sociálního pozadí zájmu. Přehlédneme-li panorama české meziválečné sociologie, uvidíme, že Bláhova sociologie města byla činem bezesporu zakladatelským a na dlouhou dobu i ojedinělým (mimo Bláhu až pražská skupina roku 1938). Zakladatelským nejen pro svou prvotnost, ale také proto, že vše směřovalo $\mathrm{k}$ tomu, že se tato disciplína bude po válce dále rozvíjet. Roku 1946 byl učiněn rozsáhlý výzkum Brna, pod Bláhovým vedením a realizovaný jeho žáky. Č́st výzkumu se sice dočkala i svého zpracování, nikoli už publikace. Společenské poměry přestaly být vědě o společnosti nakloněny a došlo k přetržení jedné české sociologické tradice. ${ }^{10}$ Jak vyplývá $\mathrm{z}$ přehledové stati J. Musila o poválečném vývoji sociologie města v Evropě i Americe (Musil 2003), v době opětovné obnovy sociologie v 60. letech se určitého pokračování dočkala pražská linie, orientovaná více na sociálně morfologické stránky města. Orientace sociologie města byla $\mathrm{v}$ té době určována problémy bytové výstavby, územního a sociálního plánování. Těmto cílům pochopitelně vyhovoval více styl kvantitativní analýzy městských prostorových potřeb, převzatý z americké tradice sociální ekologie, než více kvalitativní přístup Bláhův, směřující spíše k analýze životního stylu.

\section{Bláhova česká sociologie města ve světovém kontextu}

V románu britského spisovatele D. Adamse Stopařuv průvodce po galaxii nalistoval hlavní hrdina v př́ručce pro galaktické stopaře pod heslem „Země“ jediné slovo - „neškodná“. Ani rozšířená verze hesla, znějící „převážně neškodná“, neumenšila jeho smutek. Podobně by asi vypadalo heslo „Bláhova sociologie města“ v hypotetickém sociologově galaktickém průvodci. Vliv žádný nebo malý, to je osud sociologií uzavřených do malého národního jazyka, tedy i osud Bláhův. Mezinárodní vliv není však jediným kritériem kvality vědeckých děl a teorií. Pro vystižení pozice Bláhovy sociologie města v dobovém kontextu je nezbytné její

9 Podle: Bláha 1997: 104-105.; Musil 1996: 1097. Spoluautor Machotka byl se stavem americké sociologie dobře obeznámen, nebot publikoval v roce 1937 knihu Americká sociologie zachycující vývoj sociologie v USA.

10 Bláha ve své kronice zmiňuje mezi svými domácími hosty ze svých žáků dr. Ptáčka, „který sice zpracoval jako své doktorské téma část výzkumu města Brna (Brněnský občan a kino), ale poněvadž se svou prací byl hotov až v době, kdy už se sociologické disertace odmítaly, dosáhl doktorátu na fakultě př́ríodovědecké na téma z kulturní antropologie“ (Bláha 2003: 191). O zlomech v české sociologické tradici a problémech jejího opětovného oživení pojednává M. Petrusek (2006). Prvním zlomem byl rok 1940, druhým rok 1948, třetím rok 1989. 
srovnání s nejvlivnějšími směry sociologické tradice. $Z$ dnešního pohledu lze rozlišit přibližně trri velké klasické směry a postavy sociologie města: Weberovo zkoumání města jako způsobu emancipace z etablované mocenské struktury, založené na bohatém historickém materiálu; Simmelovy subtilní analýzy specificky městské psychiky; výzkumy a práce členů Chicagské školy, zejména Parkovy a Burgessovy.

Rozdíly zmiňovaných pozic vyvstanou již na úrovni př́stupu, a to zejména mezi americkou a evropskou sociologií. V tomto ohledu se Bláha jeví jako typicky evropský sociolog. Zatímco v Evropě dominoval historický príistup (zejména u Bláhy a Webera, Simmel vzhledem k projektu hledání apriorních sociálních forem se až tak silně historií nezabýval, o to více směřoval $\mathrm{k}$ filosofii), Američany zajímala současnost. To je pochopitelné, uvědomíme-li si, že americká velkoměsta vyrostla tak ř́kajíc přes noc na zelené louce, zatímco města evropská jsou výsledkem často tisíciletého vývoje a proměn. Podle D. Martindalea způsobila historizující orientace evropské sociologie vědomé a rozsáhlé odřiznutí amerických sociologů od evropské sociální teorie města (Martindale 1958: 46). Tyto rozličné prístupy pravděpodobně způsobily další rozdíl - v Evropě se kultivovala sociologie „,“ městě, zatímco v Americe sociologie „ve“ městě. Pokud se přidržíme předmětu zájmu této studie - Bláhovy sociologie města - nalezneme v Bláhově prístupu snahu důsledně pojímat město jako jeden sociální celek, sociální jev sui generis. Proto Bláha tematizuje, co lidi ve městě spojuje (viz např́iklad jeho hledání typu maloměstské morálky, která je nad částečnými morálkami všedního dne apod.). Naopak v práci amerických sociologů převládá vidění města jako agregátu různých sociálních světů. I přes úvodní konstatování o specifičnosti města jako celku zabírá daleko nejvíce místa problematika diferenciace a segregace městského obyvatelstva i fyzického prostředí. Ilustrativním i symptomatickým př́íkladem budiž Parkovo tvrzení, že lidé, kteří se na ulici mohou vzájemně dotýkat lokty, žijí reálně ve zcela odlišných světech (Park 1925: 26). Tematizace diferencí v americké sociologii je možná prirozenou reakcí na multikulturní realitu amerických měst. Zároveň však podle našeho názoru vedla k orientaci na deskriptivní způsob sociologické práce. Důsledkem tohoto směřování pak byla absence sociologické teorie města, kterou $\mathrm{v}$ americké sociologii konstatoval Martindale ještě koncem padesátých let (Martindale 1958: 19 a n.) Je pravděpodobné, že zmiňovaný nedostatek sociologické teorie způsobila i specifická orientace americké sociologie na prírodní vědy, proti které se Bláha i jiní evropští sociologové ohrazovali (viz například naši zmínku o sporu Durkheim - Tarde a jeho řešení u Bláhy v diskusi subjektivismus versus objektivismus; jako jiný př́klad budiž alespoň jmenován spor o metodu duchovních věd na přelomu století - pojednaný v jiných kontextech na stránkách tohoto časopisu ${ }^{11}$ - nebo weberovské založení sociologie jako specifické „rozumějííi“ vědy). Základy americké teorie města byly v ekologickém přístupu, přejatém z prrírodních věd a uvedeném do sociologie v paradigmatickém díle americké sociologie města The City McKenziem a Burgessem. Pojmy ekologické teorie - naprríklad expanze, koncentrace, decentralizace, nahrazení, selekce apod. - však stěží mohly vystihnout sociální specifičnost městského života. Stejně dobře platily pro život vesnický, pro říši zviŕat nebo rostlin. Je pěkné vědět, že lidé jedí proto, že mají hlad, a jedí to, co mají v dosahu dopravních technologií. Tato bezesporu pravdivá koncepce objasní umístění města podél řeky, avšak málo

Srov. Sociální studia, 2005 , č. 2: 71-91. 
prrispěje k vysvětlení toho, proč měštané někdy jedí jednohubky a popíjejí koktejly (srov. Martindale 1958: 32). Problémem americké sociologické teorie byla její nesociologičnost, tedy určitý typ redukce, proti kterému evropští sociologové typu Bláhy nebo Durkheima velmi bojovali. Tento př́istup samozřejmě nelze paušalizovat, například Parkovy stati jsou naturalistické spíše deklarativně, obsahově se svým esejistickým stylem a psychologickým kladením problémů blíži Simmelovi. Ale jedná se opět více méně o deskriptivní skici vynikající jistě svou sociologickou imaginací, nikoli však schopností teoretické syntézy. ${ }^{12}$ Ta koneckonců nebyla ani Parkovým cílem (srov. Park 1925a: 3). Zatímco v USA směřoval sociologický zájem o město ke vztahům v prostoru, v Evropě se sociologové zabývali více psychologickým rozměrem sociálních vztahů.

Ovšem nejsou to jen rozdíly oproti americké meziválečné sociologii, které vystihují specifičnost Bláhova př́stupu. Rozdíly jsou patrné i v rámci evropské tradice. V první části tohoto textu byl u Bláhy konstatován specificky funkcionální př́stup pro postižení městského fenoménu. Tento př́istup je odlišným výkladovým principem než př́stup Weberův nebo Simmelův. Weber nehledí na funkci sociálního jevu ve funkcionálně vyšším celku jako Bláha, ale jeho vysvětlení hledá ve (weberovsky definovaném) smysluplném sociálním jednání s jeho významem pro jednající. Proto když čteme Weberův výklad vzniku západní městské společnosti (komunity), nalézáme tam historii politické emancipace měštanstva na základě společných zájmů, konkrétního mocenského tlaku a boje o hmotné statky. Weberova analýza je velmi přesvědčivá, nejen pro velké množství zpracovaného historického materiálu přihlížejícího $\mathrm{k}$ lokálním zvláštnostem a specifikám vývoje, ale právě pro princip vysvětlování skrze pochopitelné individuální a skupinové zájmy (především ekonomické) ovlivňující formování městské obce. Co z „,pouhé“ historie města dělá historizující sociologickou teorii, je Weberova aplikace metodiky ideálního typu. Ta umožňuje Weberovi formulovat zobecňující závěry i preses odmítnutí systematické sociologické teorie stanovující platné zákony vývoje po vzoru prrírodních věd. Tak Weber např́iklad sestavil tř̆ ideální typy městského seskupení - obchodní, výrobní a spotřební město (Weber 1978: 1215) nebo ideální typ západního města (Weber 1978: 1226). Podobným způsobem založeným na podrobné historické srovnávací práci vypreparovává obecný typ vývoje západního města v protikladu k městům východu a městům antiky (srov. např́iklad Weber 1997: 216-222). Zatímco Bláhův funkcionální př́stup tenduje $\mathrm{k}$ vysvětlení sociálních jevů shora, jejich funkcionálním podřazením vyššímu sociálnímu celku nebo teorii dějin, Weberova analýza jde zdola a spokojuje se s nalezením typických rysů vývoje. Slabinou jeho metody rozumějícího vysvětlení sociálna je hledání individuálního smyslu i tam, kde třeba žádný není, kde je třeba hledat vysvětlení jevu skutečně v řádu sociálním, o něž se snaží Bláha; případně omezení sociologie na jevy vysvětlitelné rozumějícím způsobem.

Ve srovnání s Bláhou i dalšími diskutovanými teoriemi byla Simmelova sociologie města ovlivněna jeho metodologickým projektem formální sociologie. V eseji „Metropole a duševní život" (Simmel 1971) zasazuje svou analýzu do kategoriální polarity jednota a mnohost transponované do sociologické roviny ve vztahu individuum a společnost. Podle Kellera je „(v)eškerá Simmelova sociologie [...] vlastně popisem nejrůznějších aspektů [...] roztržky mezi

12 Máme na mysli zejména Parkovy stati o městské povaze (Park 1925d), magických prvcích v moderním městském myšlení (Park 1925e) nebo tulácké duši (Park 1925f). 
jedincem a společností a popisem důsledků, $\mathrm{k}$ nimž vede marná snaha tuto osudovou roztržku překonat nějakou formou zprostředkování“ (Keller 2004: 337). Tak se Simmelova sociologie města omezuje právě na analýzu sociálních struktur, které jsou relevantní pro vztah individua a toho, co jej přesahuje. Simmel neusiluje o teorii města samotného, jako se snaží Bláha. Jeho cílem je vystižení městského typu osobnosti.

Je zřejmé, že jednotlivé metodické př́stupy v sobě obsahují určité „ontologické závazky“. Formálně odlišná optika implikuje interpretační rámec a určité teoretické závěry. Bláhova funkcionální a strukturní analýza města vede k jiným formulacím než ekologický př́stup zaměřený na prostorové vztahy, a ten zase $\mathrm{k}$ jiným poznatkům než Weberova historická analýza ideálních typů nebo Simmelova filosofující sociologie. Vznikající filosoficko-metodologické otázky plynoucí z multiparadigmatické povahy sociologie přenecháme pro tuto chvíli jiným a učenějším disputacím. Svoji pozornost zaměříme spíše na skutečnost, že přestože všichni diskutovaní badatelé budovali své př́stupy i teorie v podstatě odděleně (viz 2. bod v „Závěru“), po rozkrytí pojmových odlišností vykazují jejich analýzy značné shody. $\mathrm{Z}$ důvodů předmětného zájmu této statě si za východisko jejich porovnání zvolíme již výše citovanou Bláhovu definici, že „městskost sociálních jevů vyjádřena jest pokrokem a tendencí $\mathrm{k}$ individualisaci, $\mathrm{k}$ racionalisaci a k solidarisaci“" (Bláha 1914: 17).

Bylo řečeno, že města jsou podle Bláhy zdrojem společenského pokroku a dynamiky. Oproti venkovskému prostředí je město místem, kde se sociální život řítí vpřed. Někdy slepě, a proto je $\mathrm{v}$ životě celku společnosti venkov nutnou kotvou a prvkem stability plynoucí $\mathrm{z}$ tradice. Dynamika městského života se odvozuje z koncentrace a hustoty sociálních interakcí. Simmelovy úvahy jsou $\mathrm{v}$ těchto ohledech velmi podobné. Základem, na kterém vyrůstá městská individualita, je zintenzivnění emočního života množstvím nakupených dojmů. Metropole vytváŕí takové psychické podmínky spěchu, tempa, mnohočetné ekonomiky, které zasahují i sociální život (Simmel: 1971). Peníze, podle Simmela symbol i prostředek moderních sociálních vztahů, se stávají cílem, o který lze usilovat v podstatě kdykoliv, tedy i neustále. Odtud jeden z pramínků městského životního tempa (Simmel 1997: 20). Také klasikové Chicagské školy věnují, podobně jako Bláha, poměrně velké množství místa kořenům společenské dynamiky na městské půdě. Pro její zachycení používají pojem „mobilita“ v jeho specifickém významu. „Pohyb, který je signifikantní pro růst, implikuje změny pohybu v odpovědi na nový stimul nebo situaci. Změna pohybu tohoto typu se nazývá mobilita“ (Burgess 1925: 58). „Mobilita, [...] zahrnuje změnu, novou zkušenost, stimulaci. [...] Pro osobu, jakož i pro fyzický organismus, je stimulace podstatou růstu“" (Burgess 1925: 59). Pojem mobility u představitelů Chicagské školy zdaleka neznamená jen přemístování v prostoru. Zahrnuje četnost a rozličnost komunikačních interakcí, charakterizuje proměnlivost, flexibilitu, nestálost městských sociálních situací (kromě Burgesse srov. Park 1925a: 15-23; Park 1925b: 80-81; Park 1925f). Rozdíly mezi autory jsou v interpretacích této dynamiky, založené na mnohosti sociálních interakcí. Díky pojetí městské dynamiky jako pokroku zdůrazňuje Bláha ty její stránky vedoucí k novým tvůrčím procesům, dílům, hodnotám. Oproti tomu Burgess nebo Park ukazují na negativní dopad psychické nepokojnosti. Více než $\mathrm{k}$ tvoření nových hodnot přispívá $\mathrm{k}$ boření starých. „Oblasti mobility jsou zároveň oblastmi mladistvé delikvence, gangů, chudoby, rozvodů, nemanželských dětí, neřesti. Tyto konkrétní situace ukazují, proč je mobilita snad nejlepším indexem stavu městského metabolismu“ (Burgess 1925: 59). Parkova analýza tulácké mentality také vidí spíše negativní 
stránku nově nabyté svobody pohybu jako ceny za ztrátu domova, cíle, životní stability (Park 1925f). O Simmelovi je známo, že ambivalentnost a tragédii života zašifroval téměř do každé svojí práce. Je mimo jeho pozornost, zda stimulace a četnost interakcí vede k tvůrčímu životu, jak tvrdí Bláha. Tyto charakteristiky však podle Simmela jednoznačně vedou např́klad k blazeovanosti a sociální lhostejnosti v mezilidských vztazích (Simmel 1971).

Weber se vzhledem ke svému retrospektivnímu historickému zaměření na středověké město a svému rozumějícímu přístupu (vysvětlení z perspektivy individuálních aktérů) v analýzách městskosti zvláštní interakční dynamice nevěnuje. S Bláhou i všemi ostatními autory se však stýká v otázce racionalizace městského, potažmo moderního života, které je jeho výsostným tématem. Ve svých analýzách ekonomických dějin konstatuje na mnoha místech specificky západní racionalitu, podporující kapitalistickou ekonomiku racionálního kalkulu (oproti vývoji na východě nebo v antice). Spoléhání se na vlastní racionální hospodaření odlišuje nejvíce středověké evropské město od antické polis, která byla spíše vojenským táborem hoplitů - vyzbrojených občanů (Weber 1997: 222). Všichni autoři, nejdůsledněji asi Simmel ve Filosofii peněz (Simmel 1991), spojují racionalizaci městského života s rozvojem peněžní ekonomiky a peněžní formy styku. V intencích optimistické pokrokářské interpretace vidí Bláha ústup iracionality jako možnost vzniku nových objektivních hodnot (estetických, mravních) na racionálním základě. Zaměřuje se na sociální podmíněnost vzniku vědy na městské půdě, coby nejobjektivnější formy poznání. Naproti tomu skeptik Simmel, když už ne kriticky, tedy minimálně ironicky, upozorňuje na pokřivení mezilidských vztahů peněžní kalkulovatelností, redukující kvalitu na kvantitu, emotivní na racionální vztahy.

Moderní městská individualizace je u Bláhy spojena se získáním svobody a autonomie (politické - městská samospráva, intelektuální - věda, mravní - humanitní etika). Podobně je Weberova analýza zaměřena na otázky politické emancipace. Weber považuje zákonodárnou autonomii a samosprávu za dva z pěti základních znaků ideálního typu západní městské komuny (Weber 1997: 178). V opozici k tomu zdůrazňují američtí sociologové negativní rysy rostoucí městské individualizace, spočívající ve vyvázání z primárních sociálních vztahů zajišstujících efektivní sociální kontrolu a v následném nárůstu sociálně patologických jevů. Pod Simmelovým drobnohledem se zase v městské individualizaci začíná odrážet metropolitní extravagance, intelektuální distance, anonymita a cizost.

Otázka městské solidarity přesahuje užší rámec sociologie města a je obecnou sociologickou otázkou po vazbách, které poutají stále autonomnější individua. V Durkheimových intencích Bláha tvrdí (alespoň ve spisech k sociologii města), že mravní význam dělby práce spočívá v tom, že vytváří nová pouta solidarity. Městská solidarita je zároveň racionální. Je ztělesněna nejen v uvědomění si společenské funkce své i ostatních lidí, jejich nezbytnosti, ale i v nových racionálních hodnotách, které dávají pozitivní základ společenskému konsensu (např́iklad hodnota autonomie, svobody individua apod.). Nový typ solidarity, který je druhou stranou mince moderní městské individualizace, nenalézá u většiny dalších autorů podobně pozitivní interpretaci. V protikladu k harmonickému Bláhově vidění vztahu jedince a celku spatřuje Simmel v rozporu individuality a nadřazené síly společnosti nejhlubší problém moderního života (Simmel 1971). Velkoměsto je místem, kde se podle něj individualismus stýká se systémovými požadavky v nejvystupňovanější podobě (Keller 2004: 348). Nová solidarita má u Simmela fragmentární charakter. Diferenciaci podléhají nejen jedinci, ale i skupiny. Každý člověk, a zvláš- 
tě městský člověk, náleží zároveň do různých skupin a s každou z nich jej poutají individuální zájmy. Celospolečenská solidarita je výsledkem propojení, které vytvář́ individuum svým členstvím v mnoha často nepodobných skupinách. Vyvstává před námi model solidarity jako koláže, jejímž pojivem je integrita individua, spojující v jednotu mozaiku jeho partikulárních členství (srov. Keller 2004: 338-339). Sociální vazby, které vytvářejí a umožňují peníze, jsou racionální a neosobní. Solidarita, kterou podporují, je stejně silná jako odvolatelná a přenosná. Bláhově koncepci racionální solidarity je blízký model ideálního diskurzu tmeleného sdílenou hodnotou racionální objektivní pravdy. Simmelovu představu vystihuje spíše představa svazku, který je uzavírán podle racionálního zvážení zisku a ztrát. Racionalitou je prosycena i Weberova koncepce moderní solidarity. Je spojena s jeho teorií postupující racionalizace, charakterizující vývoj moderní společnosti. Postupující racionalita na jednu stranu rozbíjí jednotu tradičního společenského uspořádání, udržovaného náboženstvím, do řady dílčích subsvětů (Weber: 1998), na druhou stranu se stává principem umožňujícím určitou převoditelnost těchto světů, jak je vidět z principů legálního panství a fungování byrokracie (Weber 1978, 1997). Důrazem na institucionální mechanismy zajištující sociální rád jsou Weberovu pojetí blízcí představitelé americké sociologie. Konstatují úpadek tradičních mechanismů sociální kontroly ve městech a jejich nahrazování sekundárními a racionálními mechanismy (racionálním právem, zájmovými kluby, vzdělávacími experty apod.) (srov. Park 1925a: 23-33, Park 1925c, Park 1925d: 113-114). $\mathrm{Z}$ uvedené komparace je patrné, že diskutovaní badatelé se většinou shodují v deskripci nejdůležitějších charakteristik a procesů městského sociálního života, které Bláha pojmenoval jako racionalizaci, individualizaci a solidarizaci. Rozdíly vyvstávají v interpretaci těchto procesů. U Bláhy se často odvíjí od pojmu pokroku a vede ke zdůrazňování jejich kladných aspektů. Zda jsou rozličnost interpretací i výběr zdůrazňovaných stránek těchto procesů způsobeny odlišností paradigmat či osobností, můžeme ponechat pro tuto chvíli nerozřešeno.

\section{Závěr: Bláhova sociologie města včera a dnes}

Přehlédneme-li souhrnně Bláhovu sociologii města a načrtnuté panoráma české i světové sociologie města, dospějeme minimálně ke čtyřem relevantním zjištěním.

1. Bláha je průkopníkem českého sociologického výzkumu města. Realizoval pravděpodobně první sociologický výzkum města pomocí dotazníku. Publikoval první českou sociologickou teorii města a urbanismu.

2. Z hlediska světové sociologie se Bláha jeví jako původní badatel. Ačkoli znal práce Simmelovy i Weberovy, v kontextu jeho sociologického zájmu o město mají jen marginální význam. Svoji monografii o městě psal v době, kdy Weberovy práce o městě nebyly publikovány, stejně jako práce Parkovy. ${ }^{13}$ Simmel se u Bláhy dočkal ,akademického čtení“ v tradič-

13 Ačkoli Park svou úvodní studii ze sborníku The City sepsal již v roce 1914, publikována byla až roku 1925. Weberova analýza města zpracovávaná asi ve stejnou dobu jako Bláhova vyšla poprvé až roce 1920 .

14 Tuto akademickou recepci Simmela v Čechách - zaměřenou na formální rozbory jeho Sociologie a marginálně oceňující to, co je dnes ze Simmela živé, totiž Filosofii peněz - rozebírá Petrusek (1997: 185-189). 
ním duchu ${ }^{14}$ - tj. Bláha věnoval pozornost jeho formální sociologii a filosofii. Bláhova teorie města je bezprecedentním uchopením tohoto fenoménu modernity nejen po stránce obsahové, ale i metodologické. U žádného dalšího z diskutovaných badatelů nenalezneme práci s dotazníky - tímto sociologickým nástrojem par excellence. Bláhovo dotazníkové šetření je pravděpodobně také jedním z prvních v sociologii vůbec. ${ }^{15}$ Jeho funkcionální přístup (vycházející z Durkheimova pojetí funkce) se jeví jako svébytný interpretační rámec vedle historizujícího př́stupu Weberova, filosoficko-psychologických analýz Simmelových a ekologického pojetí představitelů Chicagské školy.

3. K charakteristice Bláhova funkcionálního př́stupu patří i určitá praktická orientace sociologického úsilí vedená terapeutickým zájmem o problémy doby. Pro tuto svou praktickou orientaci se Bláha jeví jako typický český badatel. Praktická orientace není jen charakteristikou klasické české sociologie (v dílech Masaryka, Beneše, Fischera), ale odpovídá i praktické orientaci převládající v českém filosofickém myšlení včetně positivismu. ${ }^{16}$

4. Konečně v otázce Bláhova vlivu doma i v zahraničí je nutno zkonstatovat malou odezvu. V zahraničí z pochopitelných důvodů jazykových, později i politických (zákaz v zahraničí žádaných překladů některých Bláhových prací po válce). Domácí vliv Bláhův leží spíš v institucionálně podporované sociologii venkova. Slibně obnovenou poválečnou tradici sociologie města, vycházející z Bláhova semináře, opět přerušil mocenský zásah spojený se zrušením sociologie. Jejího dalšího oživení v 60. letech se již Bláha nedožil. Pozdější česká sociologie města se vydala kvantifikujícím směrem, řešícím spíš konkrétní otázky bytové výstavby než výstavby obecné teorie.

Otázka vlivu nás přivádí $\mathrm{k}$ úvaze nad tím, zda je na Bláhově sociologii města dnes něco aktuálního, případně co je tímto aktuálním. Pro tematickou omezenost textu nás nyní nezajímá obecná otázka, proč se zabývat v sociologii klasiky a jakým zpo̊sobem to přispívá k rozvoji oboru. Spíše se zamysleme nad tím, co je na Bláhových výzkumech města věcně plodného, podnětného nebo současného. Otázka vhodnosti funkcionální analýzy města (v Bláhově smyslu) není ani tak problém na poli sociologie města jako spíše úvah metodologicko-filosofických. Můžeme však říci, že Bláhovo založení funkcionální analýzy na rozboru sociálních potřeb je vhodným přístupem při řešení praktických sociálních problémů. Obdobně založenou funkcionální sociologii města pro potřeby sociálního plánování koneckonců pěstovali například polští sociologové v šedesátých letech (Musil 2003: 151). Analýza nových potřeb a nezbytných funkcí by našla jistě své místo při řešení řady sociologicky významných urbánních problémů, jako je například rezidenční segregace, revitalizace sídlišst apod. ${ }^{17}$ Metodologicky aktuální je Bláhova kombinace kvantitativních a kvalitativních metod. Podívat se na různorodé zdroje dat, které používá pro poznání městského života, má význam minimálně inspirač-

15 Přesné údaje o historii dotazníků nemáme $\mathrm{k}$ dispozici. Práce se statistikami a sběr kvantitativních dat pozorováním byly použity už při výzkumu chudoby v Anglii na sklonku 19. století. Rozvoj dotazníkové metodologie a inferenční statistiky v sociologii je spojen nejvíce s P. Lazarsfeldem zhruba od 30. let 20. století.

16 K českému positivismu a jeho odlišnosti od evropského pozitivismu jeho praktickou orientací a bytostným př́konáním naturalismu srov. Cetl 1981.

17 Určitý přehled nových urbánních problémů v ČR podává Illner (2003) a kolektiv autorů Horská, Mauer a Musil (2002: 298-331). 
ní. Z hlediska obecné teorie města se Bláhovy klíčové pojmy (racionalizace, individualizace, „nová" solidarizace) jeví jako použitelný aparát, zasazující město do určité teorie modernity, kterou v hlavních obrysech sdílí i ostatní „klasikové“. Individualizace společnosti je legitimním a aktuálním tématem dnešní sociologie (ne nadarmo zní název jedné z posledních knih Z. Baumanna (2004) Individualizovaná společnost), stejně jako racionalizované formy styku a sociální vazby. Oproti tomu vývoj sociologie dospěl k odmítnutí hodnotícího pojmu pokroku pro vysvětlování sociální reality, který je v Bláhově (rané) sociologii patrný a omezuje tak převzetí některých jeho interpretací.

Zaměřme se nyní na konkrétní Bláhovy rozbory města. Vzhledem k proměnám, které od roku 1925 prodělal svět práce, je Bláhův empirický výzkum sedláka a dělníka sociologickým archaismem. Použít jej lze leda k ilustraci historických proměn sféry práce. Ani to však není zcela zanedbatelný př́nos. Archaismem však zajisté není intence Bláhova výzkumu: přispět $\mathrm{k}$ sociální typologii. Aktuálnost tohoto záměru dosvědčují shodné snahy v sociologii postmodernity Z. Baumana (2002). ${ }^{18}$ Baumanova typologie městských osobnostních vzorců jistě nepostrádá sociologickou imaginaci a filosofickou hloubku, Bláhovou předností je zakotvení v empirii. Bláhovy sociální typy nejsou abstrakce, ale osobnostní vzorce vymezené objektivními sociálními charakteristikami, konkrétně povoláním. V návaznosti na Bláhu se lze ptát, zda existují nějaké sociální typy charakteristické pro svět práce v dnešním velkoměstě. Stejně známý jako vágní je koncept symbolického analytika. Je snad prototypem světa práce pozdně moderní doby? Má svůj typový protipól, např́ílad v lokálně uvázaném nezaměstnaném?

$\mathrm{Na}$ určitou mezeru v sociologických výzkumech města upozorňuje Bláhova sociologie malého města. K přezkoumání se nabízí otázka, zda je $\mathrm{v}$ dnešní době malé město skutečně sociálním specifikem. Absenci současných výzkumů malého města si uvědomují i současní čeští urbánní sociologové (Horská, Mauer a Musil 2002: 308). Je určitou domácí zvláštností, že po roce 1989 česká malá města jako soubor obyvatel početně rostla, i když globální trendy mluví o migraci ve prospěch metropolí. Pro možnou aktualizaci Bláhových výzkumů - ovšem v nových teoretických i empirických kontextech - hovoří mj. dnešní částečný návrat ke strukturám z doby před 2. světovou válkou, doplněný novými ekonomickými a technologickými faktory (Horská, Mauer a Musil 2002: 301). Nejen američtí sociologové (Sassen) a zastánci teorie nerovnoměrného vývoje poukazují na skutečnost, že podoba současných měst je velkou měrou ovlivněna procesy akumulace a soutěže různých forem kapitálu. Také někteří čeští sociologové zdůrazňují, že „,diferenciace měst je v současné době především důsledkem jejich vzájemné soutěže“ (Horská, Mauer a Musil 2002: 313) v nejrůznějších oblastech. Důraz je často kladen na ekonomické faktory soutěže o investice. Bláhův text o vznikající estetické tradici na malém městě (Bláha 1912f) lze vzít jako pracovní hypotézu a přezkoumat konstrukci novodobých městských tradic jako součást dnešních městských strategií v kumulaci

18 Bauman vykresluje čtyři postmoderní osobnostní vzorce, které pojmenovává zevloun, tulák, turista a hráč. V jeho eseji je cítit inspirace G. Simmelem.

19 Např. znojemská „hroznová koza“ je výsledkem racionální volby tradice chtivých měšt’anů a jejich rozhledu v antické mytologii, nikoli vyústěním lidové tradici. Ve strategickém plánování města Brna se uvažuje, jak vytrhnout město z mezinárodní anonymity. Po érách „moravského Manchestru“ a „města výstav, veletrhů a Grand Prix“ se rýsuje „město univerzit“. 
symbolických forem kapitálu. ${ }^{19}$ Kalkulace symbolického kapitálu má reálný dopad např́klad na rozdělování městských dotací, symbolický kapitál může hrát významnou roli v motivacích migrace obyvatel (zdravé životní prostředí, město zeleně, město vzdělání atd.), určitými způsoby může stimulovat př́liv dalších forem kapitálu apod. Dichotomii město - venkov dnes nahrazuje spíše koncept polarity centra a periferie (Hannerz 1996). Lze v rámci tohoto schématu umístit maloměsto? A kam? Došlo k Bláhou prorokovanému poměštění venkova, nebo gravitační síla velkoměstských center odstředila malé obce na skutečnou periferii, ze které mohou vyrazit jen jednotlivci (za prací, vzděláním, zábavou), nikoli však obec jako sociální celek, jak napovídají současné výzkumy suburbanizace (Sýkora 2003)? Tyto a další otázky vzbuzuje dnes Bláhova sociologie města. Jejich zodpovězení je však otázkou jiných textů a výzkumů než je tento.

\section{Literatura}

Bauman, Z. 2002. Úvahy o postmoderní době. Praha: SLON.

Bauman, Z. 2004. Individualizovaná společnost. Praha: Mladá fronta.

Bláha, In. A. 1908. Duše malého města. Disertační práce. Univerzita Karlova, Praha.

Bláha, In. A. 1908. „Individuum a společnost.“ Česká mysl, IX: 437-445

Bláha, In. A. 1909. „Národnost ze stanoviska sociologického.“ Česká mysl, X: 289-299, 366-375.

Bláha, In. A. 1911. „O politické tradici na malém městě.“ Lidové noviny (pod čarou třikrát).

Bláha, In. A. 1912a. „Vývoj positivnosti v sociologii.“ Hlídka Času, č. 190, 231, 248.

Bláha, In. A. 1912b. „O některých směrech současné sociologie.“ Česká mysl, roč. XIII, s. $289-305$.

Bláha, In. A. 1912c. „Psychosociologický objektivism.“ Česká mysl, roč. XIII: 393-405.

Bláha, In. A. 1912d. „O sociologických metodách.“ Studentská revue: 74-78, 138-142.

Bláha, In. A. 1912e. „Kritický realism v sociologii.“ Česká mysl, roč. XIII: 52-58, 172-186.

Bláha, In. A. 1912f. „Smysl pro umění na malém městě.“ Čas, č. 231: 6.

Bláha, In. A. 1912. „Maloměstská morálka.“ Česká mysl, roč. XIII: 96-102.

Bláha, In. A. (neuveden) 1913. „Maloměstský parasitismus.“ Středa, roč. II: 30.

Bláha, In. A. 1913-1914. „K psychologii malého města.“ Lidové noviny, roč. XXI, č. 199: 1-2;

č. 213: 1-2; č. 223: 1-2; č. 254: 1-2; č. 268: 1-2; č. 274: 1-2.; roč. XXII, č. 30: 1-2.; č. 35:

1-2; č. 41: 1-2; č. 65: 1; с̌.72: 1-2.

Bláha, In. A. 1914. Město. Studie sociologická. Praha: Melantrich.

Bláha, In. A. 1914. „Psychické vlivy městského prostředí.“ Česká mysl, roč. XV.: 7-18.

Bláha, In. A. 1920. „Malé město a jednotlivec.“ Horácké listy, roč. XII, č. 50: 1-2.

Bláha. 1925. „Město a venkov.“ Brázda, roč. VI, č. 2: 33-38.

Bláha 1925. Sociologie sedláka a dělníka. Praha: Orbis.

Bláha 1996-2004. „Rodinná kronika.“ Universitas (př́loha na konci každého čísla).

Burgess, 1925. „The Growth of the City: An Introduction to a Research Project.“ In R.

Park (ed.) The City, Chicago - Illinois: University of Chicago Press, s. 47-62.

Cetl, J. 1981. Český pozitivismus. Př́spěvek k charakteristice jedné z tradic českého buržoazního myšlení. Brno: UJEP.

Durkheim E. 1926. Pravidla sociologické methody. Praha: Orbis. 
Durkheim, E. 2004. Společenská dělba práce. Brno: CDK.

Hannerz, U. 1996. Transnational Connections. London: Routledge.

Horská P., Maur E., Musil J. 2002. Zrod velkoměsta. Urbanizace českých zemí a Evropa. Praha - Litomyšl: Paseka.

Illner, M. 2003. „Úvodem k monotematickému číslu Soudobé město v měnící se společnosti.“ Sociologický časopis: 132-135.

Keller, J. 2004. Dějiny klasické sociologie. Praha: SLON.

Martindale, D. 1958. „Prefatory Remarks: The Theory of the City.“ In M. Weber The City, New York: Collier Books, Free Press, s. 9-67.

Masaryk, T. G. 2002. Sebevražda. Praha: Masarykův ústav AV ČR.

McKenzie, R. D. 1925. „The Ecological Approach to the Study of the Human Community.“ In Park (ed.) The City, Chicago - Illinois: University of Chicago Press, s. 63-79.

Musil, J. 1996. „Sociologie města.“ Slovníkové heslo in Velký sociologický slovník, Praha: Karolinum, s. 1097.

Musil, J. 2003. „Proměny urbánní sociologie ve Spojených státech a Evropě 1950- 2000.“ Sociologický časopis:137-163.

Nový, L. 1994. Filosof T. G. Masaryk. Problémové skici. Brno: Doplněk.

Park, R. 1925a. „The City: Suggestions for the Investigation of Human Behavior in the Urban Enviroment.“ In Park (ed.) The City, Chicago - Illinois: University of Chicago Press, s. 1-46.

Park, R. 1925b. „The Natural History of the Newspaper.“ In R. Park (ed.) The City, Chicago - Illinois: University of Chicago Press, s. 80-98.

Park, R. 1925c. „Community Organization and Juvenile Deliuency.“ In R. Park (ed.) The City, Chicago - Illinois: University of Chicago Press, s. 99-112.

Park, R. 1925d. „Community Organization and Romantic Temper.“ In R. Park (ed.) The City, Chicago - Illinois: University of Chicago Press, s. 113-122.

Park, R. 1925e. „Magic, Mentality and City Life.“ In R. Park (ed.) The City, Chicago - Illinois: University of Chicago Press, s. 123-141.

Park, R. 1925f. „The Mind of the Hobo: Reflections upon the Relation between Mentality and Locomotion." In R. Park (ed.) The City, Chicago - Illinois: University of Chicago Press, s. $156-60$.

Petrusek, M. 1994. „TGM: Sociologie mezi vědou a uměním.“ In Tomáš Garrigue Masaryk a sociologie. Sborník z konference. Hodonín, s. 28-39.

Petrusek 1997. „Proč číst Simmela na konci tisíciletí?“ In G. Simmel Peníze v moderní kultuře a jiné eseje, Praha: Slon, s. 159-192.

Petrusek, M. 1999. „Místo Emanuela Chalupného ve vývoji československé sociologie.“ In Emanuel Chalupný, česká kultura, česká sociologie a Tábor, Praha: Filosofia, s. 59-75.

Petrusek, M. 2006. „Trojí renesance české sociologie (1945-1989) a tři velké mýty o jejím znovuzrození." Nepublikovaný rukopis.

Rádl, E. 2003. O Německé revoluci. K politické ideologii sudetských Němců. Praha: Masarykův ústav AV ČR.

Sedlák, J. 1995. Inocenc Arnošt Bláha. Brno: MU.

Simmel, G. 1971. „Metropolis and Mental Life.“ In On Individuality and Social Forms, Chicago: University of Chicago Press. 
Simmel, G. 1990. The Philosophy of Money. London: Routledge.

Simmel, G. 1997. Penize v moderní kultuře a jiné eseje. Praha: Slon.

Sýkora, L. 2003. „Suburbanizace a její společenské důsledky.“ Sociologický časopis.

Tarde, G. 1901. Zákony sociální. Praha.

Weber, M. 1978. Economy and Society. Los Angeles: University of Califfornia Press.

Weber, M. 1997. Autorita, etika, společnost. Praha: Mladá fronta.

Weber, M. 1998. „Věda jako povolání.“ In M. Weber Metodologie, sociologie, politika, Praha: Oikúmené, s.109-134.

Zouhar, J. 2000. Minulý konec století. Brno: MU.

\section{Autor}

Dušan Janák je doktorandem katedry sociologie Fakulty sociálních studií Masarykovy univerzity. Zabývá se dějinami sociologického myšlení (tématem jeho disertace je sociologie I. A. Bláhy), sociální filosofií a filosofií sociálních věd. V těchto oblastech publikoval několik článků a statí v odborných časopisech. Kontakt: 16938@mail.muni.cz 